\title{
Reflexivity on stories of conflict among Latin American teenage school girls in a multicultural school in Madrid
}

\author{
Adriana Patiño-Santos \\ University of Southampton, UK
}

Text received 31 October 2016, accepted 2 November 2016, final version 9 November 2016 DOI: http://dx.doi.org/10.5565/rev/jt13.690

\begin{abstract}
This paper looks at forms of reflexivity and the moral positioning of social actors, displayed in conversational narratives about school conflict, co-produced by Latin American girls during sociolinguistic interviews with a female researcher of Latin American origin, in a multicultural school in the centre of Madrid. Understanding narratives as communicative practices makes them suitable discursive spaces for revealing the moral positioning and moral orders constructed in discourse. These discursive positionings need to be considered in the light of the ethnographic conditions under which such narratives emerge (Patino-Santos, 2016). Herein, I analyse narratives recounting conflicts from two different groups - female secondary school students and their teachers - based on the notion that it is in recounting and evaluating moments of conflict that social actors call upon their systems of beliefs and values. The failure of the girls' secondary school and all the negative repercussions of such failure are central to problematising the social circumstances in which their narratives are produced.
\end{abstract}

Key words: school failure, Latin American students, school conflict, narrative analysis

\section{Resumen}

Este artículo estudia algunas formas de reflexividad y de posicionamiento moral en narrativas conversacionales sobre el conflicto escolar. Estas narrativas fueron coproducidas por jóvenes de origen latinoamericano en entrevistas con una investigadora, también latinoamericana, en un instituto de secundaria multicultural, ubicado en el centro de Madrid. La comprensión de las narrativas como prácticas comunicativas permite estudiar en ellas posicionamientos y órdenes morales construidos discursivamente. Tales posicionamientos deben ser considerados a la luz de las condiciones etnográficas dentro de las cuales las narrativas fueron producidas (Patino-Santos, 2016). En este artículo analizo narrativas que relatan conflictos con dos grupos de oponentes: compañeras de clase y docentes, tomando como base la noción de que al relatar y evaluar momentos conflictivos, los actores sociales evocan sistemas de creencias y de valores. Comprender las razones por las cuales las jóvenes fracasan en la escuela secundaria y las repercusiones negativas de tal fracaso son centrales para cuestionar las circunstancias sociales dentro de las que las narrativas son producidas.

Palabras clave: fracaso escolar, estudiantes latinoamericanos, conflicto escolar, análisis narrativo 


\begin{abstract}
Resum
Aquest article estudia algunes formes de reflexivitat i de posicionament moral a narratives conversacionals sobre el conflicte escolar. Aquestes narratives van ser coproduïdes per joves d'origen llatinoamericà, a entrevistes amb una investigadora també llatinoamericana, a un institut de secundària multicultural, al centre de Madrid. L'enteniment de les narratives com a pràctiques comunicatives permet d'estudiar en elles posicionaments $\mathrm{i}$ órdens morals construïts discursivament. Tals posicionaments han de ser considerats al llum de les condicions etnogràfiques dintre dels quines són produïdes (Patino-Santos, 2016). En aquest article analitzo narratives que expliquen conflictes amb dos grups d'oponents: companyes de classe i docents, prenent com a bas la noció que en explicar i avaluar moments conflictius, els actors socials evoquen sistemes de creences $\mathrm{i}$ valors. Comprendre el fracàs de les joves a l'escola secundària $i$ les repercussions negatives d'aquest fracàs són centrals per qüestionar les circumstàncies dintre de les quines les narratives són produïdes.
\end{abstract}

Paraules clau: fracàs escolar, estudiants d'Amèrica Llatina, conflicte de l'escola, anàlisi narratiu

\title{
Introduction
}

The closure in 2008 of the secondary school Evangelista, located in the centre of Madrid, demonstrated the shortcomings of the local government's policies of reception and schooling for migrants arriving from the mid-1990s onwards. As has been extensively reported in previous research (Patiño-Santos, 2009, 2011a, 2011b; MartínRojo, 2010) Evangelista presented all the ingredients of failure). In creating a concentration of students of migrant backgrounds, it precipitated the flight of children of Spanish backgrounds whose parents preferred to send them to state funded or religious schools in the area. Half of the staff members were on temporary contracts, while the other half were close to retirement, making it difficult to create a strong and unified pedagogic project. Meanwhile, the reduction in the number of students eventually became structurally unsustainable. By the end of the school year 2006-2007, a building designed for 650 students hosted only 66 students for the four years of Compulsory Secondary Education (1-4 ESO). Locally, the confrontational interactions between the students and the teachers both within and outside the classroom, as well as mass media reporting of violence in the school, helped to destroy its reputation.

I conducted research in the school from the school year 2003/04 until its closure. From the very beginning, I focused on understanding and documenting the conflictive 
relationships between all the participants in the centre, but the gaps between girls' discursive reflections on life, including the importance of school, and their actual behaviour were of particular interest to me. From the beginning of our informal exchanges, these girls, aged between 13 and 17, would affirm the importance of school in achieving a better future, but then their thoughts would turn to life concerns that $\mathrm{I}$, in thinking of my own academic trajectory at their age, considered more relevant to adults: issues such as being in love, getting married and having children. The issues that I observed and recorded, as well as their shared narratives, led me to question the naturalised behaviours apparent amongst the Latin American girls in this school.

The main purpose of this paper is to contribute to the research on language, youth, mobility and reflexivity in late modernity from an integrated narrative and linguistic ethnographic perspective, which claims that the analysis of conversational narratives (CNs) must bring to the fore the ethnographic conditions under which such narratives emerge and circulate (Patiño-Santos, 2016). The understanding of CNs as social practices (De Fina \& Georgakopoulou, 2008) acknowledges their interactive and situated nature and makes them suitable discursive spaces for uncovering the logics of practice underpinning tellers' courses of action.

The data represent situations and circulating discourses amongst and about girls of Latin American backgrounds that I have observed repeatedly in subsequent linguistic ethnographies in Spanish multilingual schools where Latin Americans were concentrated (Codó \& Patiño-Santos, 2014, Patiño-Santos, 2009). The analysis of the narratives gathered in this context will provide an account of the ways social actors give account of their own behaviour through positioning themselves as moral agents, during the course of the narrative construction. Constructing oneself as a moral agent in storytelling, in this particular setting, implies recalling, a story where the teller is the main character, responding physically or psychologically to unexpected events provoked by opponents to illustrate something that the protagonist considers fair or appropriate. In the narratives, the moral agent vests herself to evaluate others' behaviour and, in some cases, demand justice. This is based on particular moral orientations, a code of conduct that defines what it means to be a good person, a good friend, fair, etc. My presence at the school at different moments in the school trajectory of these girls, as well as my knowledge of some of the situations depicted in their stories, established me 
as a co-producer of their stories and as a storyteller of the situations that I studied (Rowe, 2003).

The second section of this text will discuss $\mathrm{CN}$ in linguistic ethnography, as the epistemological approach followed in this paper while the following section presents the method and data. The analysis will discuss narrative episodes of reflexivity in terms of the girls' positionings as moral agents in stories of conflict at school with different social actors: peers and teachers. Girls' participation in conflictive situations and the ways in which they overcome such difficulties become central focuses for reflexivity regarding the courses of action reported by the protagonists. Finally, the last section of this text will be devoted to the discussion of the contradictions between the ideologies upheld in the girls' discourses and their actual behaviour as evidenced by their school trajectories.

\section{A (socio)linguistic ethnographic approach on reflexivity and moral positioning in narrative}

Narrative has been understood as one of the most suitable discursive genres to study how identity and related issues, such as positioning, stance and categorisation are constructed and negotiated in daily life practices (De Fina \& Georgakopoulou, 2011).

Narrative analysis in sociolinguistics has always addressed certain aspects of "reflexivity", though never under that name, when considering the discursive and interactional devices and strategies that tellers use in order to fulfil certain communicative purposes. Thus, in their seminal sociolinguistic approaches to narrative, Labov and Waletzky (1967), and later Labov (1972) identified key components of the narrative (abstract, orientation, complicating action, resolution, evaluation and coda), giving evaluation a central role as the element of the narrative in which the teller suspends the action in a critical moment taken to present his/her views on the situation or the subjects depicted in the narration. It is in this evaluation that the reason for narrating certain events becomes explicit.

This initial attention to evaluative aspects of the narrative would become important within discursive studies that focussed on narrators' forms of 'positive' selfrepresentation, and later on interactional approaches (Ochs \& Capps, 2001, Georgakopoulou, 2007) interested in narratives as sites for the local construction of identities and the negotiation of social realities (De Fina \& King, 2011). Such studies 
have all shown, amongst many other issues, that through narrative the teller can accomplish particular communicative and argumentative purposes, such as lending credibility, resolving tensions and conflict (Schiffrin, 1996), negotiating identities, justifying his/her behaviour and opinions (Carranza, 1999, van Dijk, 1993), displaying agency (Georgakopoulou, 2006) and defending moral positions (Relaño-Pastor \& De Fina, 2005; Vásquez, 2007). As has been well evidenced empirically, "Narrative is not simply a pervasive discursive form, but a resilient and versatile resource through which speakers can accomplish many different social and cultural actions" (Thornborrow \& Coates, 2005, p. 6).

The acknowledgement of narratives as interactional forms embedded in daily life conversations (Capps \& Ochs, 2001, Georgakopoulou, 2006) or more recently in interviews (Thornborrow \& Coates, 2005, De Fina \& Georgakopoulou, 2010; Kohler Riessman, 2015) has opened up the possibility of exploring reflexivity in narratives which goes beyond the interactional work of the speakers to include the analysis of the tellers' positionings on different communicative levels. Thus, inspired by Davies and Harré's theory of positioning (1990), some authors have pointed out the ways in which narrators construct themselves as characters in relation to other characters in the depicted world, but also as co-tellers in the communicative situation wherein the narrative is being produced, and at the same time they position and align themselves in relation to other subjects and circulating discourses (or master narratives) beyond the immediate communicative situation (Bamberg \& Georgakopoulou, 2008, Wortham, 2001).

I understand CNs as they are defined by Ochs and Capps (2001): i.e. as referring to those interactionally embedded stories that do not necessarily follow a linear plot and that might evoke past, present or hypothetical future events. They are social activities co-constructed and negotiated by all the participants in the interactional setting. Their heteroglossic nature allows the depiction of characters whose voices are included, making them powerful resources to express and negotiate moral positions in order to justify actions and choices, which might vary over the course of the narrative (e.g. Baynham, 2003; Bucholtz, 1999; De Fina, 2003; Georgakopoulou, 2007; Schiffrin, 1996; Vásquez, 2007). Such polyphony entails the enactment of multiple stances that may be in tension, or plain contradiction, within the various events portrayed during the narrative (Bakhtin, 1984). 
In analysing the narrative, I consider the ethnographical conditions in which it has been produced. This is beneficial in two regards: firstly, it reveals the discrepancy between what is affirmed by social actors in their communicative practices and the reality of their own trajectories. In this regard, Bourdieu's notion of habitus, understood as "the systems of durable, transposable dispositions, structured structures predisposed to function as structuring structures" (Bourdieu, 1990, p. 53), becomes, as noted by Reay "a method for simultaneously analysing 'the experience of social agents and... the objective structures which make this experience possible' (Bourdieu 1988, p. 782)" (Reay, 2004, p. 439). That is, habitus helps us to identify and unveil the rules, beliefs, and attitudes regarding what counts as being a "niña de su casa" a "good" girl who complies with the norms laid down by her parents.

At the same time, it allows the researcher to reflect upon his/her own participation as a researcher in the field at the moment of gathering the data (to explain the motivations for certain questions, for example). In my particular case, it also prompted a revisiting of the relationships first established with the other participants, nearly a decade ago, along with my own expectations directed towards the girls that I interviewed at that time (see Koehler Riessman 2015 for a discussion on revisiting data from a reflexive perspective).

\section{Method and data}

Even though I collected narratives produced in six group interviews, for the purposes of this paper I focus on the CNs gathered in group interviews with two opposing circles of friends from $4 \mathrm{~B}$ that dealt with conflictive relationships between the female students and their peers, their teachers and their parents. The first circle, led by Lady (Colombian, 17), consisted of Isabel (16, born in Madrid of Filipino background and identified by her teachers as "The Filipino from 4B"), and Jose (17), of Spanish origin. Jose was the only boy of Spanish origin in 4B. The members of the second circle were Carolina (16), the leader, Soraya (17) and Eugenia (16), of Ecuadorian backgrounds. The girls from the two circles used to confront each other, mostly verbally and especially in the final months. The only one who was born in Madrid was Isabel and the others had arrived in Madrid at secondary school age, none having lived there for more than three or four years. With the exception of Lady, the Ecuadorian girls had been assigned to Evangelista by the local education authority. Lady had spent one year in a 
previous school where she had felt bullied by her classmates. Having heard that Evangelista hosted a majority of Latin American students, she had asked to be transferred there in 2005. All these girls portrayed themselves as "stay-at-home" girls ("niñas de su casa"), so I was intrigued to discover the reasons they might give for fighting and how they dealt at home with the fact that they were failing the final year of their compulsory education.

The analysis focusses on the construction of moral positioning and a moral order in the narrative repertoires of Latin American girls in Evangelista school. Constructing oneself as a moral agent in storytelling, in this particular setting, implies recalling in the communicative setting of the group interview, a story where the teller is the main character, responding physically or psychologically to unexpected events provoked by opponents to illustrate something that the protagonist considers fair or appropriate. In the narratives, the moral agent vests herself with the authority to evaluate others' behaviour and, in some cases, demand justice. This is based on particular moral orientations, a code of conduct that defines what it means to be a good person, a good friend, fair, etc.

I draw on analytical tools associated with conversational narrative (Ochs \& Capps, 2001), such as the identification of narrative components (unexpected event, setting, response, consequence and evaluation), episode, voicing/dialogism (Bakhtin, 1984), along with an ethnographic perspective that helps to shed light on the conditions of production of such narratives and the ideologies and wider social phenomena that they index.

Each excerpt will present the ways in which these girls draw on conversational storytelling in order to present themselves as moral agents, and the resources they use to align themselves (or otherwise) with certain moral orders. Field notes, along with my reflections on my participation in the field and in the production of the data will allow me to contrast the moral order constructed in the storytelling, in which importance is given to academic attainment, with the girls' actual academic trajectories in the compulsory education system in Madrid between 2003/04 and 2006/2007. All of these girls either had repeated or were currently repeating a year. The contradictions between their positionings displayed discursively and what the students actually do will be relevant in discussing the habitus that is being reproduced by these young Latin 
American migrants in diaspora. Teachers' perceptions of the situation allowed me to widen the picture.

\section{Analysis: The feminine world of Latin Americans in Evangelista}

The Latin American girls in Evangelista were integrated in friendship circles. During 2003/4, my first long visit, I observed that most of the circles were wide and gender mixed. During the breaks, the $1^{\text {st }}$ and $2^{\text {nd }}$ year girls used to sit in groups around the playground to see and cheer on the boys playing basketball or football. The oldest girls, who were in the $3^{\text {rd }}$ and $4^{\text {th }}$ years, used to be in the cafeteria with their boyfriends or groups of friends, chatting and having coffee. In this first stage of my research, the girls dressed variously, but those with a 'sexy' hip hop aesthetic (tops, skinny trousers, leggings and hoodies) stood out. The school celebrations were animated by hip hop and reggaeton and dancers, in groups or couples, presented choreographies emulating Daddy Yankee ${ }^{1}$ 's performances.

In 2006/7, the situation had changed dramatically. The visibly reduced number of students had obliged the school administration to close the cafeteria. The long breaks of 30 minutes had disappeared and were replaced by two fifteen-minute breaks. Most of the boys had dropped out of the school and you could see small groups of girls (typically in threes) wandering around the corridors, since students were not permitted to go outside the school to buy snacks. They were supposed to bring sandwiches from home, something that the girls disliked because they felt treated like primary school children. Thus, for example, Sandra, from year 3B, complained that this practice was simply "not cool". This new eating arrangement caused the students to organise themselves differently. Friends clubbed together into groups, which, though they might represent a mix of nationalities, were typically led by someone of Colombian or Ecuadorian background - these being the most widely represented nationalities in the school. The girls of Dominican, Moroccan or Filipino backgrounds, also represented at this school, stuck with one group or another, but Colombian and Ecuadorian girls rarely mixed with each other. The two groups also presented quite differently in public spaces. While Colombians payed extreme attention to their clothes, figures, hairstyles and make-up, Ecuadorians were much less 'showy', with less jewellery and without the tight clothes typical of the Colombians, who wore flashy leggings and 'sexy' tops. 
This section is divided into three parts. Each one presents one or two CNs in which the girls narrate and evaluate confrontational situations involving three groups of opponents: girls of rival cliques (5.1.1), their teachers (5.1.2) and their parents (5.1.3).

\section{Fights between girls}

Fights between students in Evangelista were one of the marked disciplinary problems in the school. At the beginning of my research, in 2003/04, staff members reported problems of conflict between gangs of the boys in the school. The head teacher at that time recalled that students had been fighting at the main entrance and enumerated some of the given reasons, such as revenge between gangs. However, two or three years later, I started to realise that the most frequent fights were not between the boys but between the girls. In the different interviews and conversations carried out during my fieldwork, many reasons emerged for the girls to fight. Basically they mentioned a sort of "code" that should be respected: envy between girls was a cause of conflict that should be avoided, along with malicious gossiping (chismes), betrayal and the stealing of boyfriends. Especially during the year 2005/6, when the upper floors of the building were empty due to the reduced number of the students. According to witnesses, the girls used to fight on the empty fourth floor, in the toilets, and in some areas of the playground that were not monitored by the teachers. They mainly fought close to the school entrance, after home time.

Excerpts 1 and 2 present, firstly, how students in general assessed the fights between girls as something anecdotal and fun, and secondly, how girls drew on narratives to construct themselves as moral agents.

\section{1) "What's fair": Lady, Isabel, and Jose}

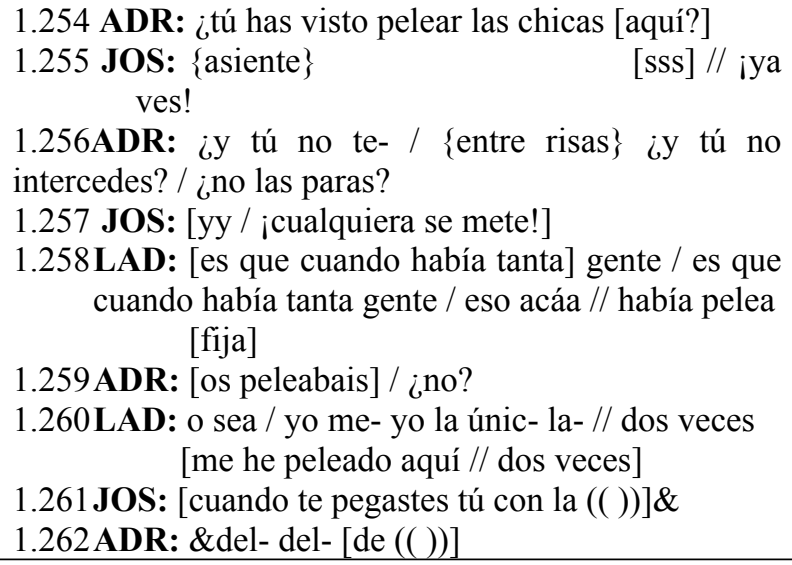


1.263 LAD: [sí / pero porque] ella mee // yo soy muy tranquila // y yo me llevo bien con // con la gente que se vaya bien conmigo / pero a mí que me saquen la rabia que $->/ /$ ((vamos)

1.264ADR: y te- $\mathrm{y}-\mathrm{/}$ ¿y te peleaste- pegaste con alguna de las chicas de $->/ /$ ¿te has pelead- / de [pegarte?]

1.265LAD: [con] Susan ->

1.266ISA: con Carolina / [¿no?]

1.267LAD: $\quad$ [yyy] / lo que pasa es que ella tien- / tenía un piercing acá en la ceja // pero que esa pelea casi no duró

1.268ADR: ya

1.269LAD: porque yo me le pegué el piercing de la ceja y del pelo y yoo / y entonces ellaa // ¿me entiend- / o sea / yo \{suena el timbre\} (( )) despacito pero como / dándole a entender a ella que si se movíaa oo si me pegaba ((duro)) / yo le- / se le arrancaba el piercing y ahí // entonces nos separaron porque ella empezó a gritar / ¡que ya no más! / ¡ya no más!

1.270STU: [risas]
1263 LAD: [yeah / but 'cos] shee // I'm very calm // I get along well with // with the people who get on well with me / but if somebody makes me mad $->/ /(($ well $))$

1264ADR: and you- and- / and did you fight with one of the girls from $->/ /$ did you fig- / [hitting?]

1265 LAD: [with] Susan ->

1266 ISA: with Carolina / [right?]

1267LAD: [and] / the thing was that she had/ she had a piercing here in her eyebrow // but that fight was short

1268 ADR: right

1269LAD: 'cause I grabbed the eyebrow piercing and her hair and III / so shee // ¿me d'you unders- / well / I \{the bells rings $\}$ (( )) slowly but like / letting her know that if she moved or hit me ((hard)) / I was- / I was gonna rip out the piercing and then // so they separated us 'cos she started screaming / enough! / enough!

1270STU: [laughter]

In this Excerpt, we can observe several issues:

First, the turns from 1254 to 1258 clearly illustrate the dominant boys' positioning regarding the fights between girls. To my direct question about girls' fights, Jose replies laughing "too right", to indicate the futility of my question. In 1257 he states the impossibility of stopping the girls in a fight ("nobody gets involved"), a recurrent comment in the data that I gathered amongst boys talking about girls' fights. The laughs, the evasive responses given by Jose and all the boys' reactions on this topic, led me to understand that fights between girls were seen by some students in the school as something trivial, anecdotal or comic. The girls I interviewed, on the contrary, took them seriously as we shall observe.

In turn 1260 , Lady decides to illustrate the point she has made in the previous turn about the fact that when there were more students at school, they used to fight more (an idea consistent with the principal's impression in 2003/04. In this example, we can observe the ways in which Lady positions herself as a moral agent in the narrative that she co-narrates with Isabel and Jose, by presenting herself as a person who is generally unaggressive, but can become violent when provoked. Thus, in 1260, she summarises the fights in which she has participated (two). Since these are shared stories (Georgakopoulou, 2007) with the circle, Jose intervenes to identify her opponent in the story). I interrupted Lady's self-evaluation in 1264 to invite her to clarify who the opponents in her narrative were "and did you fight with one of the girls..?” In 1265 the 
character "Susan" is introduced, someone who is then reformulated by Isabel as having been "Carolina". In 1267 Lady summarises the fight, without presenting the unexpected event: "the thing is that she had a piercing here in her eyebrow / but that fight was short". In 1269 she describes the events chronologically: "I grabbed the eyebrow piercing and her hair”, “... letting her know... I was gonna rip out the piercing”. Double voicing Carolina's screams during the fight with a change in the tone of voice is a way to lend credibility and emotion to the narrated event (Ochs and Capps 2001). Lady's move in voicing the opponent's screams, at the moment of defeat, to present evidence of her weakness is reinforced by the laughs of the co-tellers of the story. Turns 1263 and 1269 are used by Lady to portray herself as a moral person, both reasonable and quiet, but at the same time a good fighter, able to plan fight tactics.

The catalysts reported as provoking fights are similar to those documented by research on Latino girls in several sites in the USA (Dietrich, 1998, Mendoza-Denton, 2008). The girls at Evangelista felt provoked by various triggers: suspicious or hostile looks and pushing in the corridors were frequently reported examples. I saw groups of girls looking at others to scrutinise the clothes they were wearing. In one of the breaks, a Colombian girl told me that the Ecuadorians wore "ropa del chino" (clothes from the discount shops operated by Chinese immigrants), implying that their clothes were cheap imitations of poor quality.

Some girls felt that others acted in a superior manner, refusing to socialise with certain classmates ("they think they're better than us" / "they fancy themselves"), something that often led to negative evaluations being voiced, and sometimes to physical fights. Leading on from the previous excerpt co-produced by Lady, Isabel and Jose, excerpt 2 introduces a second narrative in which Lady expands on her reasons for confronting other girls. Through this new story, Lady continues to portray herself as a morally coherent person and to some extent a moral leader.

\section{2) "On lack of solidarity": Lady, Isabel and Jose}

1.118ADR: [¿pero tú] qué notas? // ¿por qué está dividido el curso?\&

1.119JOS: \&envidia

1.120ADR: envidia//entre: // ¿chicos y [chicas?/(( ))]

1.121 JOS: [entre chicas]

1.122ADR: $=(())$ - entre chicas

1.123 ISA: (no $(()) /$ es que entre todos [nosotros] nos llevamos bien / (( )) $\left.[(()))^{\circ}\right]$

1.124ADR: [ya ya ya // sí sí sí\&
1.118ADR: [but what] do you notice? // why is the class divided?\&

1.119JOS: \&envy

1.120ADR: envy//between: // boys and [girls?/(( ))]

1.121 JOS: [between girls]

1.122ADR: $=(())$ - between girls

1.123 ISA: (no (( )) / it's that [we] all get along well together/ $\left.((\quad))[(()))^{\circ}\right]$

1.124ADR: [right right right // yes yes yes\& 


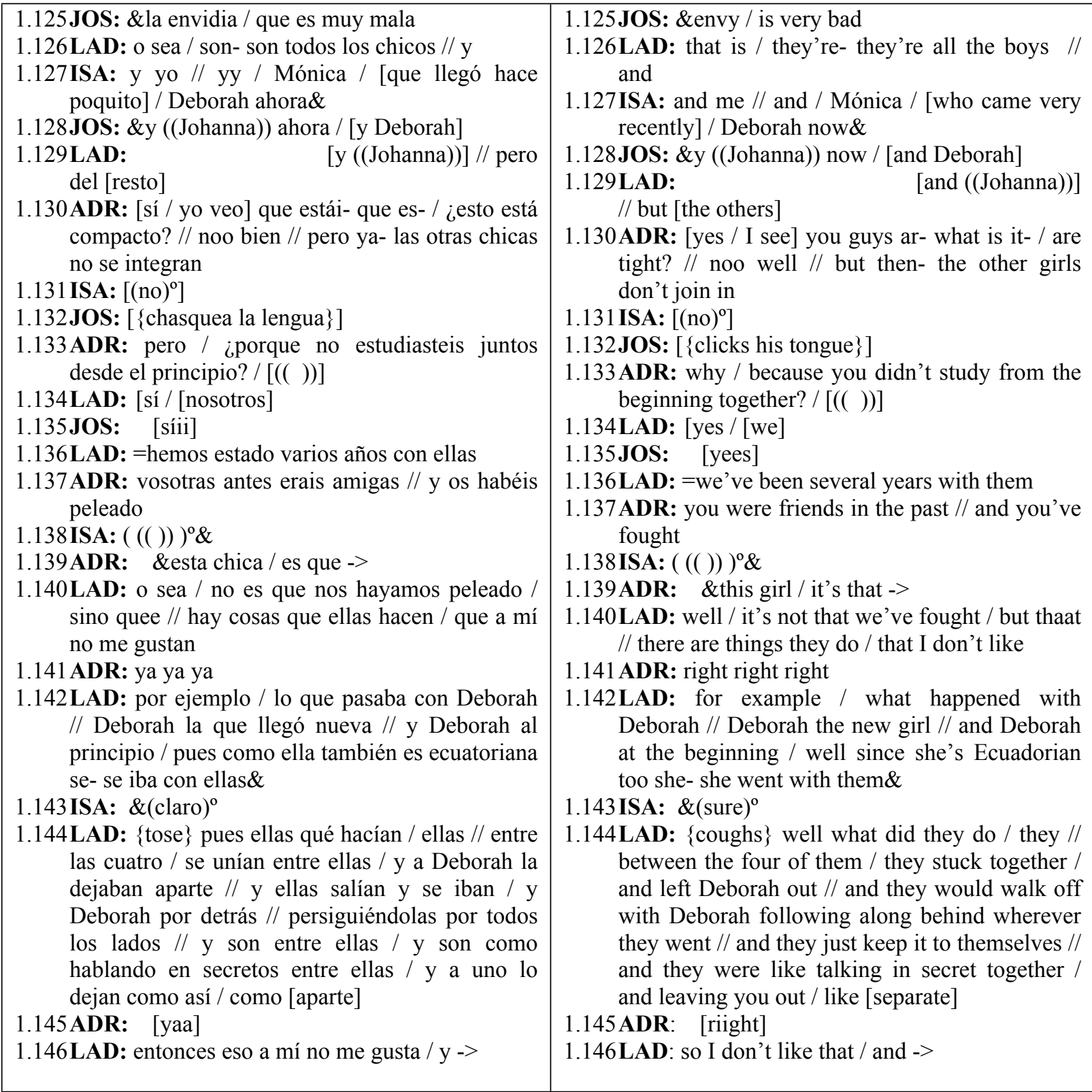

After a few turns in which Jose, Lady and Isabel try to explain the reasons why class 4B is "divided", Jose in two turns (1119 and 1121) makes clear to me that the main cause of disagreements in the class is envy amongst the girls, something that he evaluates negatively in 1125 ("envy is very bad"). In 1123, Isabel starts to enumerate those who have a good relationship, constructing implicitly the category of those who do not. In 1123, she identifies the group by using the pronoun "we" assigning the predicate "get along well", and between 1126 and 1129 Lady, Isabel and Jose list the names of those who get on well: "all the boys, Isabel, Mónica, Deborah and Johanna".

Knowing the tense relationships with the group of Ecuadorian girls in the class (Carolina, Eugenia, Soraya and Susan, who had since left to join a Catholic school), in 
1130 I ask about "the other girls". Since their answers are not conclusive, I decide to reformulate the question in two different turns (1133 and 1137). Finally, in 1140, Lady starts a $\mathrm{CN}$ in which she summarises and evaluates her relationship with her opponents: "it's not that we've fought / but that there are things they do that I don't like". The CN containing this evaluation is narrated in several turns. In 1142, she introduces the character of "Deborah", identified as an Ecuadorian newcomer. Her ethnicity is brought up to explain why Deborah chose to join the group of four other Ecuadorians. This explanation is supported by Isabel ("of course"), who becomes a co-narrator in 1143. In 1144 Lady presents the behaviour of these four Ecuadorians towards Deborah. I show understanding of the situation in 1145, which leads Lady to conclude the narrative by reiterating her opinion and justifying her fight with Carolina recounted in Excerpt 1: “so, I don't like that".

From this $\mathrm{CN}$ we can understand the behaviour of the group of four Ecuadorians of whom Lady and her co-tellers do not approve morally: they form an exclusive clique, and when somebody such as the newly arrived Deborah needs them, they ignore her. By drawing attention to the behaviour of these girls, Lady is signalling what she considers to be 'correct' behaviour: newcomers should be integrated; secret conversations are not allowed; excluding classmates is not acceptable. Lady thus presents a strong argument for having fought with some of them in the past. In such cases, she feels that justice is on her side.

To sum up, in this first sub-section, we have seen the ways in which the girls portrayed themselves as moral agents in the school setting, in opposition to certain (disloyal) peers. The next section stays in the setting of the school but introduces a new group of opponents, the teachers, including some of the ways they confront them, and their reflections upon their own behaviour.

\section{Confronting the teachers}

Reflexivity in the form of moral positioning dominates in the group CNs when the circles of friends narrate conflictive situations with their teachers. The moral ethos of the group, led by the girls, emerges in the ways in which they characterise themselves and their teachers as main characters in the narrated events, as well as in their evaluations of their teachers' behaviour in conflictive circumstances. The following story, co-narrated by Carolina, Eugenia and Soraya from 4B, illustrates the moral 
positioning constructed and the moral orders towards which they orientate themselves.

Their teacher is constructed in opposition to their own behaviour and system of values:

\section{3) "The horrible tutor": Carolina, Eugenia y Soraya}

325. ADR: pero yo quiero si habéis tenido con
profesores algún tipo de $\rightarrow /=$
326. EUG: en tercero
327. ADR: =algún tipo de cosa en la que:
328. EUG: ya no / de ahí en adelante no
329. ADR: no habéis vuelto a tener con
profesores de
330. CAR: esta / este año con / en los primeros días con la profe- / con la tutora

331. SOR: ah sí / con la tutora

332. CAR: ella y yo (refiriéndose a Soraya)/ las dos (risa)

333. ADR: vosotras / qué le hacíais?

334. CAR y SOR: no! NO i / es que ella

335. CAR: fue porque ella:

336. SOR: ella era antipática

337. EUG: es que

338. SOR: ella / ella comenzaba a gritar y yo a no dejarnos gritar a nosotras / y a veces así sin tener culpa /y comenzaba- / si el otro día me mandó a mi fuera de clase /

bueno al principio y no / por no hacer- / pero no dije nada / no hice nada / estaba era hablando con ella (Carolina) /y me hizo una pregunta y yo le respondí / ¡fuera de clase! / y no y no ni le respondí ni gritando ni nada/si no así /ifuera de clase!!

339. CAR: bueno me voy /

340. ADR: ya

341. CAR: a mí / por qué era que me mandó $\uparrow /$ no me acuerdo

342. EUG: (por el móvil / por el móvil) ${ }^{\circ}$

343. SOR: no / no / no

344. CAR: ah sí / fue porque me llamaron al móvil y me llamaron del 97 y a mi cuando me llaman del 97 es porque es mi tía de Zaragoza y si me llama a esa hora es porque le pasa algo / entonces/ yo dije / mi tía / yy si yo le decía que era mi tía / no me iba a dejar salir / entonces yo le dije es mi papá / ¿puedo salir?/ me dice no / que están prohibidas / ya bueno me dejó salir / no me hizo casi problema y me dejó salir / salí y entré y me dice ee / bueno / ahí fue culpa mía / me dice ee

345. SOR: ¡no! / porque tú no le mentiste

346. CAR: sí / me dice ella voy a llamar a tu casa /no porque no ha sido mi papá / había sido mi tía / y me dice / ¡o sea que me mentiste! / dame el móvil / y que le de el móvil y le digo / no pero es que me dio permiso/ y me dio permiso porque si no
325. ADR: but I'd like to know if you and the teachers have had any sort of $\rightarrow /=$

326. EUG: in year 3

327. ADR: = any sort of thing in which you:

328. EUG: not anymore / since then no

329. ADR: you and the teachers haven't had any other

330. CAR: this / this year with / during the first few days with the teacher-/ with the tutor

331. SOR: ah yes / with the tutor

332. CAR: me and her (pointing to Soraya)/ both of us (laugh)

333. ADR: you two / what did you do to her?

334. CAR y SOR: no! $\mathrm{NO}_{i} /$ it was her

335. CAR: it was 'cos she:

336. SOR: she was horrible

337. EUG: it was 'cos

338. SOR: she / she started shouting and I 'cos we're not allowed to shout / and sometimes when it's not our fault /and she started- / yes the other day she sent me out of the class/ well at the beginning and not / for not doing- / but I didn't say anything / I didn't do anything / I was like talking to her (Carolina) / and she asked me a question and I answered / out of the class! / and I didn't I didn't reply by shouting or anything / and it was / out of the class!

339. CAR: OK I'm off I

340. ADR: right

341. CAR: with me / why was it she sent me $\uparrow /$ I can’t remember

342. EUG: ('cos of the mobile /' $\cos$ of the mobile) ${ }^{\circ}$

343. SOR: no / no / no

344. CAR: ah yes / it was 'cos they called me on the mobile and they called me from 97 and when they call me from 97 it's 'cos it's my auntie from Zaragoza and if she rings at that time it's 'cos something's happened to her / so I said / $m y$ auntie / and and if I said it was my auntie / she wouldn't let me go out / so I told her it's my dad / can I go out?/ she says no / they're not allowed / anyway she let me out / she didn't make much fuss and she let me out / I went out and came back and she says ee / well / that was my fault / she said ee

345. SOR: no! / 'cos you didn't lie to her

346. CAR: yes / she tells me I'll ring your house / no 'cos it wasn't my dad /it was my auntie / and she tells me / so you lied to me! /give me the mobile / and she asked me to give her my mobile and I say / no but you gave me permission/ and she gave me permission 'cos if not she'd have said / no / turn off the mobile / and that would be it and then she sent me down here and all that / we had 
hubiera dicho / no / apaga el móvil / y ya está y luego me bajó acá abajo y todo lo demás / tuvimos problemas

347. SOR: si / no / es que ella cuando habla y tiene razón / yo me quedo callada pero cuando no / no problems

347. SOR: yeah / right / it's like with her when she says something and she's right / I keep my mouth shut but when she's not / I don't

Given the fact that conflicts between students and teachers were one of the dominant practices in this school, I decided to ask about those situations. In the final years of Evangelista, most of the students were girls, and conflicts between teachers and girls happened more regularly than between teachers and boys or the group as a whole (Patiño-Santos, 2009). In this example, in response to my question in turn 325 about whether they had had moments of conflict with any teacher, Eugenia, in two turns, explains that there had been no such conflicts since year 3. However, my reformulated question in turn 329, triggers in Carolina a memory of two conflictive situations with their tutor, at the beginning of the current school year. Carolina initiates her own story, by offering the setting (time and main characters) in different turns: "this year with the teacher / with the tutor", and two turns later, she specifies that the two of them, Carolina and Soraya, had had a disagreement with their tutor, constructing herself and her friend as characters in the story. I, as an adult, concluded that the girls "had done something", to which the girls immediately react in order to clarify that it was the teacher's fault. Regardless of the actual facts of the situation, we then have two co-narrated CNs in which the three girls portray the teacher as unfair, in opposition to themselves as fair and honest.

In turn 338 Soraya tells her own related short story in one turn. She initiates a $\mathrm{CN}$ where she is co-protagonist of the conflict, by summarising the teacher's behaviour: "she started shouting and I 'cos we're not allowed to shout / and sometimes when it's not our fault". She starts with the resolution of the conflict "the other day she sent me out of the class" and goes on to present the main events leading up to this in chronological order: “but I didn't say anything / I didn't do anything / I was like talking to her (Carolina) / and she asked me a question and I answered". Soraya presents herself as having acted in a passive way, as a victim of circumstances, by indicating that she was just answering Carolina. The teacher's response is double voiced, "Out of the classroom!", imitating the force of the shout in a demonstration. In turn 339 Carolina intervenes to close the narrative by double-voicing Soraya's answer "OK I'm off". 
Two turns later, Carolina self-selects to tell her own conflict story with the same tutor. The fact that these experiences are shared by the members of the circle allows them to take the floor in order to complete or co-narrate anecdotes about things that have happened to their friends, or in which they were secondary characters, as we observed in the conclusion to the narrative told by Soraya previously. In this new case, Carolina forgets a detail in the anecdote that she wants to use in order to illustrate her teacher's behaviour, so Eugenia self-selects to co-construct the unexpected event ("'cos of the mobile"). Soraya takes the floor to contradict Eugenia, but Carolina aligns herself with the story initiated by Eugenia. So in TURN 344, Carolina explains her story.

Carolina starts her narration by presenting the unexpected event ("they called me from 97") giving the reasons that she had to answer a phone call during the class. This reasoning allows her to construct herself as somebody caring and concerned about her family, doing the 'right' thing. We can also observe how she reflects upon her own behaviour, when she presents the moral dilemma she had to face, either telling the truth or lying. She constructs herself as a moral agent who needed to make a decision in the face of a delicate situation. Nevertheless, in the first part of the episode, she decides to lie by saying that it was her father ringing, in order to get permission to answer the call. But once she came back into the class, the teacher inexplicably starts to tell her off. Then, displaying a reflexive action as a character in the narrated world, Carolina explains her decision to change her story and tell the truth to avoid her parents becoming involved should the teacher ring her home,. As a consequence of her admission, the teacher accuses her of having lied and confiscates the phone. Carolina is sent to the head teacher on the administrative floor below ("she sent me down here"). The teacher is thus portrayed as somebody contradictory since she initially gave her permission to answer the phone but then she tells her off and accuses her of lying.

This second episode is constructed through important resources such as doublevoicing. Carolina performs her dispute with the teacher, which lends emotion and credibility to the story as reported in previous research on conflictive relations (Carranza, 1993). The two voices are presented in a contrastive way: while the teacher's voice is represented as authoritarian by adopting a loud voice and direct style, Carolina's voice is quiet and her responses supported by reasons to behave in the way she did. Soraya closes the narrative by evaluating her own behaviour in response to their teacher's actions, based on the way in which they understand the moral principle of 
justice: "it's like with her when she says something and she's right / I keep my mouth shut but when she's not / I don't". This conclusion strengthens the point that the three girls portray themselves as reflexive by being aware of what is $\mathrm{good} / \mathrm{bad}$, and by showing that they are able to adapt to the circumstances. Carolina did not want to lie, but once she decides to tell the truth, as noted by Soraya in T345, she is punished. By describing their teacher's behaviour as unfair and contradictory, the girls construct themselves in opposition as fair, reasonable, supportive - a set of moral values that, in the end, are used by the girls to justify their own behaviour within the stories they tell.

So far, we have presented the girls' confrontational relations at school with peers and teachers. They depict themselves as moral agents who respond to morally questionable subjects (unfair, dishonest, unreliable, etc.) directly. The actions portrayed in their narratives as well as the self-justifications construct an image of reflective agents able to discern between right and wrong.

My final concern about the girls' poor academic results focussed on their parents' reactions:

\section{4) "On discipline at home"}

\section{Carolina, Eugenia and Soraya}

\begin{tabular}{|c|c|c|c|}
\hline 310. & $\begin{array}{l}\text { ADR: porque si a vosotras os castigan } \\
\text { mucho en la casa? }\end{array}$ & 310. & $\begin{array}{l}\text { ADR: 'cos do they punished you much at } \\
\text { home? }\end{array}$ \\
\hline 311. & $\begin{array}{l}\text { CAR: no- / a mi papá se le ha dado } \\
\text { últimamente por castigarme / }\end{array}$ & 311. & $\begin{array}{l}\text { CAR: no- / my dad has started to punish } \\
\text { me lately / }\end{array}$ \\
\hline 312. & $\begin{array}{l}\text { SOR: no me castigan / me hablan / me hacen } \\
\text { reflexionar / pero no así de castigarme no } \\
\text { sale / no sale / no }\end{array}$ & 312. & $\begin{array}{l}\text { SOR: they don't punish me / they talk to } \\
\text { me / they make me reflect / but punishing } \\
\text { you can't go out / don't go out / no }\end{array}$ \\
\hline 313. & ADR: y a ti? (to Eugenia) & 313. & ADR: and you? (to Eugenia) \\
\hline 314. & EUG: no/ & 314. & EUG: no/ \\
\hline 315. & CAR: pero tienen razón & 315. & CAR: but they're right \\
\hline 316. & ADR: y a ti te riñen (to Soraya) & 316. & ADR: and do they tell you off (to Soraya) \\
\hline 317. & SOR: no / últimamente no pasa/ & 317. & SOR: no / it hasn't happen lately/ \\
\hline 318. & $\begin{array}{l}\text { CAR: últimamente por culpa mía -/ no / por } \\
\text { culpa de la profa / mi papá / si yo quiero salir } \\
\text { / bueno / si yo quería salir salía / } \\
\text { últimamente se le ha dado ya por castigarme } \\
\text { / por quitarme el móvil / por ya no dejarme } \\
\text { salir / por tenerme más controlada }\end{array}$ & 318. & $\begin{array}{l}\text { CAR: lately it's my fault -/ no / it's the } \\
\text { teacher's fault / my dad / if I want to go } \\
\text { out / well / if I wanted to go out I did / } \\
\text { lately he has started to punish me / to take } \\
\text { my mobile away / not letting me go out / } \\
\text { he controls me more }\end{array}$ \\
\hline
\end{tabular}

My question in turn 310 opens the topic of punishment at home. Carolina notes a change in her father's behaviour in turn 311 ("my dad has started to punish me lately"). Soraya and Eugenia do not report any sort of punishment, but Carolina in turn 318 
decides to explain her father's change of approach. She initially takes responsibility, but immediately self repairs and places the blame on the tutor (see example 3). She contrasts the past and present situations at home: in the past, she was freer to go out, but now, after the incident with the mobile phone in class, her father controls her far more, confiscating her mobile phone and not allowing her to go out.

Of the 14 girls interviewed, six reported being controlled at home. None of them reported physical punishment but rather the types of control listed by Carolina: prohibition of the use of their mobile phones, constraints on their ability to socialise with friends and peers. The girls found ways to sidestep the prohibitions, by 'skiving off' school or indeed by confronting their parents directly - in the words of Carolina and Deborah in two different interviews: "being rebels".

\section{Concluding remarks}

The analysis of the shared confrontational experiences of a group of girls of Latin American backgrounds, gathered in group interviews, as part of an ethnographic fieldwork in a secondary school in Madrid, has allowed me to bring to the fore relevant issues on how young, migrant girls display reflexivity in their narrative practices. Since conflict was one of the distinguishing features of this school, the subject arose in all conversations with members of this site. Personal experiences of conflict recounted in narratives made these the ideal spaces in which to observe the reflexivity of social actors, since they felt obliged to position themselves morally with regard to others' behaviour and the situations depicted, and to make explicit their reasons and justifications for carrying their chosen courses of action.

In their CNs on conflict with different social actors at school, Latin American 'good' girls position themselves as moral agents and construct discursively a moral order with which they align themselves. As moral agents, these girls vest themselves with the authority to evaluate situations and others' behaviour. The narrated events and the relationships between characters, including themselves, depict them as reflexive actors aware of what is or is not acceptable in the different situations narrated. The narrators construct themselves in opposition to the others' perceived behaviour by presenting them as opponents in their narratives. Thus, the narratives on conflict with peers make relevant the moral ethos of the circle of friends, based on what they understand by loyalty ('eschewing malicious gossip', 'not stealing others' boyfriends') 
and solidarity ('sticking together'). The narratives of confrontation with teachers sometimes portray adults as unfair, contradictory and, in some cases, disagreeable.

The reflexivity displayed shows them as self-critical subjects. They were all repeating and failing the school year, but they all show an understanding of the situation and what is expected of them as students and daughters. In informal conversations and interviews, they revealed that, as students, they were aware that they needed to focus on their school work, that they should attend classes, do their homework, study to pass the exams, but they failed to do so. Their excuse, especially in the final year, was the absence of their friends at the school. They all felt that their ex-classmates were off doing something new whilst they were trapped at school until the end of the year. When I asked them about their ambitions for the future, they all wanted to be doctors or psychologists, but none of them was willing to commit to more than four or five years of further study. Such unrealistic goals appeared to contradict the notion that these girls displayed any genuine reflexivity, but I later came to realise that, on the particular question of academic studies, the girls' discourse was highly coloured by their perception of me as a researcher and their expectations as to what a person of academic background would want to hear. In reality, Lady, for example, worked at a beauty parlour in the afternoons helping out her mother, and Eugenia looked after a child at the weekends. Nine years after these interviews, I found their curriculums listed on job seeking internet sites, as in the following example:

LATEST PERSONAL EXPERIENCES

Saleswoman

Saleswoman specialising in selling corsetry, fashion and customer service as well as (stock management, inventory, merchandise management, returns and damages). Indepth work in display and shop window dressing as well sales statistics. Advanced knowledge of sales indicators, such as average sale, sale index, sale rate and transformation rate. Control of and personal motivation. Team working skills, people skills, dynamic and great keenness to learn and progress. I have no problems assimilating new concepts and taking on new responsibilities.

saleswoman

shop assistant
SKILLS

Cashier, opening up and closing, stock control, display, window dressing, shelf stacking

Regardless of their expressed wishes to continue studying, they all failed the academic year, and in Carolina's case, having been the best student in 2B (2003/04), she got pregnant and had to drop out of school. The latter days of their academic trajectories 
indicated that, at the time of my fieldwork, I was witnessing the transformation of a group of schoolgirls who felt increasingly detached from their academic lives, opting to invest only in the social dimension of school (Erickson, 1987). This was why their cliques were so relevant to them and why conflict between girls was taken so seriously by its protagonists.

All these factors led me to ask myself about the habitus produced amongst the members of these circles regarding their academic lives. What dispositions have these girls internalised from the moral order socialised through their family and educational histories? How was it that they were able to offer a rationale for their judgments on the right and wrong ways to behave as students, sometimes aligning themselves with the moral ethos of adults around them whilst simultaneously acting in contradiction to such values?

From the analysis of their narratives and in the light of their school trajectories, we observe how these girls are embedded in a moral order that allows them to navigate the school institution without committing to its norms and expectations (successfully completing the school year and observing the rules of discipline). School failure, in terms of failing academic years or dropping out, is explained by what Erickson (1986) calls the social side of school. It is with peers that these girls learn to make friends, to develop loyalties, and to adopt the moral ethos of such peers, which earns them membership of the circle. But at the same time, they learn to defend their honour, confront and exclude "enemies" physically and verbally. With teachers, rather than learning to follow the rules of the school and be proper "school girls", they learn how to avoid problems by lying, which was a common practice in Evangelista. Even though such lies create more problems when they are unmasked by the teachers, the girls continue to draw upon them as a tactic. The genuinely reflexive discourse that they display in their narratives helps them to justify their actions in conflictive situations, but a concurrent level of pseudo-reflexivity aligns them with the expectations of the adults that surround them but is belied by their behaviour, which actually distances them from the adults' world.

\section{References}

Bakhtin, M.M. (1984). Problems of Dostoevsky's poetics. Ed. and trans. Caryl Emerson. Minneapolis: University of Minnesota Press. 
Bamberg, M., \& Georgakopoulou, A. (2008). Small stories as a new perspective in narrative and identity analysis, Text \& Talk (28): 377-396. https://doi.org/10.1515/text.2008.018

Baynham, M. (2003). Narrative in space and time: Beyond 'backdrop'. Accounts of narrative orientation, Narrative Inquiry 13(2): 347-66. https://doi.org/10.1075/ni.13.2.07bay

Bourdieu, P. (1990). The logic of practice. Stanford, CA: Stanford University Press.

Bucholtz, M. (1999). You da man: Narrating the ratial other in the production of white masculinity. Journal of Sociolinguistics 3/4: 443-460. https://doi.org/10.1111/1467-9481.00090

Carranza, I. (1999). Winning the battle in private discourse: Rhetorical-logical operations in storytelling, Discourse \& Society 10(4): 509-41. https://doi.org/10.1177/0957926599010004004

Codó, E., \& Patiño-Santos, A. (2014). Beyond language: class, social categorisation and academic achievement in a Catalan high school. Linguistics \& Education 25: 51-63. https://doi.org/10.1016/j.linged.2013.08.002

Davies, B., \& R. Harré (1990). Positioning: The discursive production of selves. Journal for the theory of social behaviour, 20(1): 43-63. https://doi.org/10.1111/j.1468-5914.1990.tb00174.x

De Fina, A. (2003). Identity in narrative: A study on immigrant discourse. Amsterdam: John Benjamins.

De Fina, A., \& Georgakopoulou, A. (2008). Analysing narratives as practices, Qualitative Research, 8(3): 379-387. https://doi.org/10.1177/1468794106093634

De Fina, A., \& Georgakopoulou, A. (2011). Analyzing narrative. Discourse and sociolinguistic perspectives. Cambridge: Cambridge University Press.

De Fina, A., \& King, A. (2011). Language problem or language conflict? Narratives of immigrant women's experiences in the US, Discourse Studies, 13(2): 163-188. https://doi.org/10.1177/1461445610392135

Dietrich, L. C. (1998). Chicana adolescents: Bitches, ho's and schoolgirls. Westport CT: Greenwood.

Erickson, F. (1987). Transformation and school success: The politics and culture of educational achievement. Anthropology \& Education Quarterly, 18(4), 335-356. https://doi.org/10.1525/aeq.1987.18.4.04x0023w

Georgakopoulou, A. (2006). The other side of the story: towards a narrative analysis of narratives-in-interaction. Discourse Studies, 8: 265-287. https://doi.org/10.1177/1461445606061795

Georgakopoulou, A. (2007). Small stories, interaction and identities. Amsterdam/ Philadelphia: John Benjamins.

Georgakopoulou, A. (2014). Between narrative analysis and narrative inquiry: The long story of small stories research. Working Papers in Urban Language \& Literacies, Paper 131. Accessed 24 April 2015 from http://www.kcl.ac.uk/sspp/departments/education/research/ResearchCentres/ldc/publications/workingpapers/abstracts/WP131-Between-narrativeanalysis-and-narrative-inquiry-The-long-story-of-small-stories-research.aspx

Ochs, E., \& Capps, L. (2001). Living Narrative. Creating Lives in Everyday Storytelling: Harvard University Press.

Kohler Riessman, C. (2015). Entering the hall of mirrors: Reflexivity and narrative research, In A De Fina \& A. Georgakopoulou (Eds.), The handbook of narrative analysis (pp. 219-238). Malden, MA: Wiley-Blackwell. 
Labov, W. (1972). The transformation of experience in narrative syntax. In W. Labov (Ed.), Language in the inner city: Studies in the black English vernacular (pp. 354-96). Philadelphia: University of Pennsylvania Press.

Labov, W., \& J. Waletzky (1967). Narrative analysis: oral versions of personal experience. In J. Helm (Ed.), Essays on the verbal and visual arts (pp. 12-44). Seattle: University of Washington Press.

Martín Rojo, L. (2010). Constructing inequality in multilingual schools. Berlin: Mouton de Gruyter.

Mendoza-Denton, N. (2008). Homegirls: Language and cultural practice among Latina youth gangs. Malden, MA: Blackwell Publishing

Patiño-Santos, A. (2009). Narrando el conflicto: alumnado de origen inmigrante en un centro escolar de Madrid [Narrating Conflict: Students of Immigrant Backgrounds in a School of Madrid] Discurso y Sociedad (3), 1: 119-149.

Patiño-Santos, A. (2011a). Negotiating power relations and ethnicity in a sociolinguistic ethnography in Madrid. Journal of Language, Identity and Education, 10(3): 145-163. https://doi.org/10.1080/15348458.2011.585305

Patiño-Santos, A. (2011b). La Construcción Discursiva del Fracaso Escolar: Una Etnografía Sociolingüística Crítica en un Centro Educativo de Madrid [The Discursive construction of School Failure: a Critical Ethnographical Sociolinguistics in a School in Madrid] Spanish in Context, 8 (2): 235-256.

Patiño-Santos, A. (2016). Language ideologies in the narrative practices of Latin American parents in the Catalan education system. Working Papers in Urban Language \& Literacies, 186.

Reay, D. (2004). 'It's all becoming a habitus': beyond the habitual use of habitus in educational research, British Journal of Sociology of Education, 25 (4): 431-444. https://doi.org/10.1080/0142569042000236934

Relaño-Pastor, M., \& De Fina, A. (2005). Contesting social place: Narratives of language conflict. In M. Baynham \& A. De Fina (Eds.), Dislocations, relocations, narratives of displacement (pp. 36-60). Manchester: St Jerome Publishing.

Rowe, N. (2003). Researcher as storyteller and performer: parallels with playback theatre in Finlay. In L Gough \& B. Gough (Eds.), Reflexivity: A practical guide for researchers in health and social sciences (pp. 187-199). Oxford/Malden/Victoria: Blackwell.

Schiffrin, D. (1996). Narrative as self portrait: Sociolinguistic constructions of identity, Language in Society 25: 167-203. https://doi.org/10.1017/s0047404500020601

Thornborrow, J., \& Coates, J. (2005). The sociolinguistics of narrative. Identity, performance, culture. In J. Thornborrow \& J. Coates (Eds.), The sociolinguistics of narrative (pp. 1-16). Amsterdam/Philadelphia: John Benjamins.

van Dijk, T.A. (1993). Stories and racism. In D.K. Mumby (Ed.), Narrative and social control: Critical perspectives, (pp. 121-42). Newbury Park, CA: SAGE.

Vásquez, C. (2007). Moral stance in the workplace narratives of novices. Discourse Studies, 9(5): 653-675. https://doi.org/10.1177/1461445607081270

Wortham, S. (2001). Narratives in action. New York: Teachers College Press.

Author's information: Dr. Adriana Patiño-Santos is a Lecturer in Modern Languages at the University of Southampton. Her research interests include language socialisation, conversational storytelling, and multilingualism. Her research has been focused on multilingual practices as a lens through which to observe complex 
sociolinguistic situations (such as the presence of Latin Americans in different sites) from a sociolinguistic perspective.

Email: $\underline{\text { A.Patino@soton.ac.uk }}$

\section{Appendix}

\section{Symbols used in transcripts}

PART: participant

A (Capital letters) loud talking

aa lengthening of vowel or consonant sound

/ short pause ( 0.5 seconds)

// long pause $(0.5-1.5$ seconds $)$

(()) incomprehensible fragment

? question

- self interruption

\& latched utterances

$=$ continuation of utterance after overlapping $\downarrow$ descending intonation

$\uparrow$ rising intonation

$\rightarrow$ continuing intonation

[ ] turn overlapping with similarly marked turn

Eng: fragment in English

Ital direct speech

\footnotetext{
${ }^{1}$ Daddy Yankee is a popular Puerto Rican singer of reggaeton and hip hop, famous for his video clips and provocative, sometimes sexually explicit lyrics expounding politically controversial views.
}

To cite this article:

Patiño-Santos, A (2016). Reflexivity on stories of conflict among Latin American teenage school girls in a multicultural school in Madrid. Bellaterra Journal of Teaching \& Learning Language \& Literature, 9(3): 9-31. DOI: http://dx.doi.org/10.5565/rev/j1t3.640 